\title{
Associations between Marijuana Use and Sperm Quality in Jamaican Men: Implications for the Subfertile Male
}

\author{
$\mathrm{K} \mathrm{Carroll}^{1}$, AM Pottinger ${ }^{2}$, MD Jackson ${ }^{3}$
}

\begin{abstract}
Objective: To evaluate the associations of frequency, quantity and duration of marijuana use with sperm parameters and reproductive histories of male non-smokers and chronic marijuana users.

Methods: Semen samples and marijuana consumption histories were obtained from 94 men aged 23-72 years who attended a university-based private fertility management unit for infertility investigations between February and September 2014. Routine semen analyses were performed, and the associations of frequency and duration of marijuana use with sperm parameters and reproductive history were assessed.

Results: Lower motility was associated with higher quantities (Spearman's correlation coefficient, $\left.r_{\mathrm{s}}=-0.226 ; \mathrm{p}=0.045\right)$ and frequency $\left(r_{\mathrm{s}}=-0.234, \mathrm{p}=0.047\right)$ of marijuana smoked at a given time. However, duration of marijuana use showed no clear pattern of association with sperm quality. No significant associations were found between marijuana use and reproductive history.

Conclusion: Preliminary findings, using a small sample of subfertile men, suggested that sperm motility may be impacted by the quantity and frequency of marijuana use. Screening for excessive use of marijuana and counselling on the potential impact of the drug should be routinely considered for men being treated for infertility.
\end{abstract}

Keywords: Lifestyle, male infertility, marijuana use, sperm parameters, subfertility

\section{Asociaciones entre el Consumo de Marihuana y la Calidad del Esperma de los Hombres Jamaicanos: Implicaciones para los Hombres Subfértiles

\author{
$\mathrm{K}_{\text {Carroll }}{ }^{1}$, AM Pottinger ${ }^{2}$, MD Jackson ${ }^{3}$
}

\begin{abstract}
RESUMEN
Objetivo: Evaluar las asociaciones de la frecuencia, la cantidad y la duración del consumo de marihuana con los parámetros de la esperma y las historias reproductivas de varones no fumadores y usuarios crónicos de marihuana.
\end{abstract}

From: ${ }^{1}$ The Hugh Wynter Fertility Management Unit, The University of the West Indies, Mona, Jamaica, West Indies, ${ }^{2}$ Department of Child and Adolescent Health, The University of the West Indies, Mona, Jamaica, West Indies and ${ }^{3}$ Department of Community Health and Psychiatry, The University of the West Indies, Mona, Jamaica, West Indies.
Correspondence: Dr K Carroll, The Hugh Wynter Fertility Management Unit, The University of the West Indies, Mona, Kingston 7, Jamaica, West Indies. Email: kamali.carroll@uwimona. edu.jm 
Métodos: Se obtuvieron muestras de semen e historias de consumo de marihuana de 94 hombres de 23 a 72 años, que asistían a una unidad privada de gestión de fertilidad en la Universidad, para investigaciones de infertilidad entre febrero y septiembre de 2014. Se realizaron análisis rutinarios del semen, y se evaluaron las asociaciones de la frecuencia y duración del consumo de marihuana con los parámetros de la esperma y la historia reproductiva.

Resultados: La movilidad más baja fue asociada con cantidades más altas (coeficiente de correlación de Spearman, $\left.r_{\mathrm{s}}=-0.226 ; \mathrm{p}=0.045\right)$ y frecuencia $\left(r_{\mathrm{s}}=-0.234, \mathrm{p}=0.047\right)$ de marihuana fumada en un momento dado. Sin embargo, la duración del uso de la marihuana no mostró un patrón de asociación claro con respecto a la calidad espermática. No se encontraron asociaciones significativas entre el consumo de marihuana y la historia reproductiva. Conclusión: Los hallazgos preliminares, utilizando una pequeña muestra de hombres subfértiles, sugirieron que la motilidad espermática puede verse afectada por la cantidad y frecuencia del consumo de marihuana. El pesquisaje del consumo de marihuana y el asesoramiento sobre el impacto potencial de la droga, deben ser cuestión de rutina para los hombres tratados por infertilidad.

Palabras: Estilo de vida, infertilidad masculina, uso de marihuana, parámetros de la esperma, subfertilidad

West Indian Med J 2017; 66 (5): 570

\section{INTRODUCTION}

The relevant literature has reported a global decline in sperm quality (1). While the decline does not necessarily impact fertility rates, it is of concern for men who have borderline fertility potential (2). Studies on male infertility investigations have generally focussed on examining the quality of sperm and the technical aspects of in vitro fertilization (IVF) or how sperm quality is impacted by the stress of IVF and/or the infertility experience $(3,4)$.

Personal consumption habits or lifestyle choices which may influence sperm quality have been gaining attention over the past decade (5). Several studies have linked cigarette smoking to a modest reduction in semen quality including sperm concentration, motility and morphology (5-7). Although alcohol consumption has not been studied as rigorously as tobacco consumption, there is evidence that chronic consumption of alcohol (ie drinking alcohol for a minimum of five days a week for at least a year) has deleterious effects on semen quality $(8,9)$. Marijuana use has been examined in relation to sexual performance in earlier studies (10), but its effect on sperm quality has received little attention, although its use is as common as alcohol or cigarette consumption in the Western Hemisphere (11).

A population-based health survey of the Jamaican population (aged 15-74 years) in 2008 revealed that $30 \%$ of the participants reported having ever smoked marijuana and, among users, slightly less than half
(13.5\%) reported current use (12). However, marijuana consumption is illegal in Jamaica and, therefore, the statistics are likely under-reported. Anecdotally, while men who use marijuana present with fertility concerns, there are many chronic users who have fathered children, along with laboratory analyses of excellent sperm quality of habitual users.

Marijuana contains at least 20 active cannabinoids, with the primary psychoactive cannabinoid being delta9-tetrahydocannabinol ( $\Delta^{9}$-THC). It has been established that the endocannabinoid system (ECS) is present in the male reproductive tract (13). To date, most studies suggesting a link between marijuana and male fertility are based on findings from sea urchin and mouse models (14, $15)$ or the exogenous incubation of $\Delta^{9}$-THC with sperm in vitro (16). Moreover, these findings were inconclusive, with some data suggesting that marijuana smoking could adversely impact sperm function (17) and others identifying no impact or a positive impact (18).

With Jamaica's Dangerous Drugs (Amendment) Act 2015 resulting in new provisions for the possession and use of marijuana [smoking, medical and scientific] (19), and the reported increased use for medical purposes internationally (20), it is imperative that the effects of marijuana use on reproductive health be examined effectively. This study is part of an ongoing one in which the aim is to dissect the mechanism in which marijuana use and habits are associated with sperm quality. The 
objective of this study was to evaluate the association of marijuana use (frequency, quantity and duration) with sperm parameters and reproductive histories of male partners of infertile couples. As marijuana is a commonly used recreational substance, we also explored the social factors that may sustain use of marijuana by men with infertility concerns.

\section{SUBJECTS AND METHODS}

\section{Study design and participants}

This study was conducted between February and September 2014 at Jamaica's sole fertility management unit, a university-based private facility in Kingston. All new clients for routine semen analysis were consecutively recruited for enrolment in the study $(n=105)$; 94 consented. These were male partners of subfertile or infertile couples. All but one of the 11 men who declined to participate stated time constraints; one indicated that the questions were too personal. Using exclusion criteria of self-reported clinical history of vasectomy, obstructive azoospermia, varicocele, abnormal hormonal levels, chemotherapy or radiotherapy, no client was excluded from the study. As semen analysis was part of a routine investigation, no anatomical investigations were conducted to confirm these reports. All participants were interviewed by the same professional before their semen samples were taken. The project received ethical approval by The University of the West Indies (UWI), Mona, Ethics Committee.

Study participants were between the ages of 23 and 72 years. Prior to semen collection, they completed the standard registration form for infertility investigations at the fertility management unit which consisted of demographic data including occupation, general health and lifestyle practices, pregnancy history and medical history. They also completed a 17-item questionnaire developed by the researchers on marijuana use and social attitudes. Occupations which were classified into major groups based on the International Standard Classification of Occupations (ISCO) were labelled as low- or high-risk jobs for poor sperm parameters, ie jobs with exposure to contaminants such as agriculture and pharmaceutical, heat and metal exposure (21).

\section{Measurements}

Men were asked about their history of marijuana consumption to assess firstly if they smoked marijuana and, if so, the frequency, quantity and duration of use. Frequency of marijuana smoking was categorized using a Likert-type scale to assess rare to repeated daily consumption. The specific categories were: (a) rarely, months will pass; (b) occasionally during a month; (c) twice or more a week, but not every day; (d) at least once a day; and (e) several times a day. Quantity of marijuana was assessed with three specific variables ranging from one joint/spliff at a given time to three or more joints/spliffs. To assess duration, participants were asked at what age they began smoking marijuana, if they currently smoked and, if not, at what age they had stopped. They were then categorized as: (a) non-users who reported never having used marijuana or had a history of experimenting more than 10 years ago; and (b) chronic users who reported smoking within the past 10 years. Chronic users who had used marijuana within the past six months prior to the study $(\mathrm{n}=12)$ were separated from those who reportedly had stopped using for more than six months. However, the numbers were too few for separate analyses. Thus, current users were combined with past users. Participants also indicated options that best described their beliefs, attitudes and emotions associated with using marijuana.

\section{Semen analysis}

Each participant produced a semen sample by masturbation at the fertility management unit following recommended abstinence of two to three days. The sample was allowed to liquefy at $37^{\circ} \mathrm{C}$ for 20 minutes before analysis. The semen analysis was carried out according to World Health Organization guidelines for the assessment of volume, sperm concentration and percentage motility (22). Measurement of both sperm concentration and motility was done using a Hawksley fertility semen counting chamber. For morphology, sperm was classified as having normal or abnormal morphology according to strict criteria (23).

\section{Statistical analysis}

De-identified data were used and analysed using the SPSS data analysis program (SPSS Inc, Chicago, United States of America). Chi-square statistics were used for between-group differences of categorical variables. The Mann-Whitney U-test and Kruskal-Wallis were used to compare variables that were not normally distributed. The relationship among marijuana use, demographic, social and pregnancy history was assessed using Spearman's correlation coefficient $\left(\mathrm{r}_{\mathrm{s}}\right)$ to determine their association with sperm parameters. A $p$-value of $<0.05$ was considered as statistically significant. 


\section{RESULTS}

The mean age of the participants was 39 years \pm 8.21 years. Table 1 shows a similar proportion of men under 30 years old $(11 \%)$ and above 50 years old $(10 \%)$, and both age categories showed the same proportion of men with critically low total motile sperm counts (17\%). Sixty-eight per cent of the participants reported previous conception. Most chronic marijuana smokers were

Table 1: Characteristics of participants in the study $(n=94)$

\begin{tabular}{|c|c|c|}
\hline Characteristics & n & $\%$ \\
\hline \multicolumn{3}{|l|}{ Age } \\
\hline$\leq 30$ years & 10 & 11 \\
\hline $31-49$ years & 74 & 79 \\
\hline$\geq 50$ years & 9 & 10 \\
\hline \multicolumn{3}{|l|}{$($ Missing $=1)$} \\
\hline \multicolumn{3}{|l|}{ Occupation* } \\
\hline High & 41 & 47 \\
\hline Low & 43 & 45 \\
\hline Unsure & 7 & 8 \\
\hline \multicolumn{3}{|l|}{ (Missing = 3) } \\
\hline \multicolumn{3}{|l|}{ Marijuana use } \\
\hline \multicolumn{3}{|l|}{ Duration } \\
\hline Chronic & 26 & 33 \\
\hline Non-users/not used $>10$ years ago & 63 & 67 \\
\hline \multicolumn{3}{|l|}{$($ Missing $=5)$} \\
\hline \multicolumn{3}{|l|}{ Frequency } \\
\hline Several times a day & 12 & 13 \\
\hline \multicolumn{3}{|l|}{ Quantity } \\
\hline 2 or more spliffs/use & 44 & 47 \\
\hline \multicolumn{3}{|l|}{ Normal sperm parameters } \\
\hline Total motile sperm & 48 & 54 \\
\hline Concentration & 46 & 52 \\
\hline Percent motility & 70 & 79 \\
\hline Normal morphology & 47 & 53 \\
\hline \multicolumn{3}{|l|}{ (Missing = 5) } \\
\hline \multicolumn{3}{|l|}{ Previous pregnancy } \\
\hline Yes & 67 & 68 \\
\hline No & 24 & 32 \\
\hline \multicolumn{3}{|l|}{$($ Missing = 3) } \\
\hline \multicolumn{3}{|l|}{ Time trying to get pregnant } \\
\hline$\leq 1$ year & 30 & 32 \\
\hline $1-4$ years & 38 & 40 \\
\hline$>4$ years & 26 & 28 \\
\hline \multicolumn{3}{|l|}{ Other substance use } \\
\hline Cigarettes & 12 & 13 \\
\hline Alcohol & 54 & 58 \\
\hline
\end{tabular}

* Risk of exposure to occupational hazards known to be detrimental to sperm between 31 and 49 years old (68\%), with $12 \%$ aged 50 years or over and $20 \%$ aged 30 years or under. Similar proportions of the participants reported high- $(47 \%)$ and low-risk (45\%) exposure to occupational hazards known to be detrimental to sperm. Sixty-seven per cent of the participants reported never having used marijuana or had experimented more than 10 years ago.

When pregnancy history and/or sperm parameters were analysed with marijuana use, no significant associations were identified. However, as expected, more persons with normal sperm count (45\%) reported having got someone pregnant compared to those with severe oligozoospermia or borderline oligozoospermia (31\% and $24 \%$, respectively; $p=0.03$ ).

Table 2 describes semen parameters and marijuana use. It shows that sperm parameters did not vary with the pattern of marijuana use (duration, frequency and quantity). However, quantity and frequency of marijuana use were significantly correlated with per cent motility: the larger the quantity $\left(\mathrm{r}_{\mathrm{s}}=-0.226, p=0.045\right)$ and frequency $\left(r_{\mathrm{s}}=-0.234, p=0.047\right)$ of marijuana smoked at a given time, the lower the per cent motility (Table 3 ).

An examination of the beliefs and practices of habitual users who had fertility concerns revealed that most $(60 \%)$ reported smoking marijuana in the evening/night, that smoking was triggered by certain emotions eg a state of happiness $(35 \%)$ and stress $(23 \%)$, and that 6 of 10 attributed its use to enhanced sexual performance. When compared to men who were non-users of marijuana, significantly more chronic users reported having used other substances such as cigarettes or alcohol prior to the marijuana habit ( $46 \%$ vs $13 \% ; p=0.001)$, and $14 \%$ reported currently smoking cigarettes and $61 \%$ reported currently consuming alcohol.

\section{DISCUSSION}

To date, most studies suggesting a link between marijuana use and male fertility are predominantly based on findings from animal models as well as in vitro studies (14-16). Therefore, this study extended the literature on lifestyle practices and fertility potential by specifically examining levels of marijuana consumption on sperm quality in subfertile men. With the presence of a functional ECS in the male reproductive tract (13), to which $\Delta^{9}$-THC is a strong exogenous agonist, coupled with the increase in the medicinal and recreational uses of marijuana, this study was timely and pertinent.

We found that self-reported marijuana use had a negative association with sperm quality. Specifically, men who reported smoking several joints/spliffs per session 
Table 2: Marijuana use and median values (range) of sperm parameters

\begin{tabular}{|c|c|c|c|c|c|c|c|c|}
\hline \multirow[b]{3}{*}{ Marijuana use } & \multicolumn{8}{|c|}{ Parameters } \\
\hline & \multicolumn{2}{|c|}{$\begin{array}{c}\text { Concentration } \\
\left(\times 10^{6} / \mathrm{mL}\right)\end{array}$} & \multicolumn{2}{|c|}{$\begin{array}{l}\text { Motility } \\
\text { (\%) }\end{array}$} & \multicolumn{2}{|c|}{$\begin{array}{c}\text { Total motile sperm } \\
\left(\begin{array}{l}\left(\mathrm{x} \mathbf{1 0}^{6}\right)\end{array}\right.\end{array}$} & \multicolumn{2}{|c|}{$\begin{array}{c}\text { Normal morphology } \\
(\%)\end{array}$} \\
\hline & $\begin{array}{l}\text { Median } \\
\text { (range) }\end{array}$ & $p$ & $\begin{array}{l}\text { Median } \\
\text { (range) }\end{array}$ & $p$ & $\begin{array}{l}\text { Median } \\
\text { (range) }\end{array}$ & $p$ & $\begin{array}{l}\text { Median } \\
\text { (range) }\end{array}$ & $p$ \\
\hline Duration & & 0.82 & & 0.13 & & 0.98 & & 0.84 \\
\hline Chronic current & $6(0-69)$ & & $33(0-70)$ & & $19(0-171)$ & & $3(0-8)$ & \\
\hline Chronic past & $19(0-120)$ & & $54(0-73)$ & & $30(0-179)$ & & $4(0-5)$ & \\
\hline Not using & $26(0-91)$ & & $58(0-80)$ & & $20(0-479)$ & & $4(0-6)$ & \\
\hline Frequency & & 0.92 & & 0.47 & & 0.69 & & 0.54 \\
\hline Daily & $19(0-120)$ & & $54(0-73)$ & & $27(0-175)$ & & $4(0-6)$ & \\
\hline $1-2$ times weekly & $15(0.01-76)$ & & $54(0-73)$ & & $40(0-479)$ & & $3(0-5)$ & \\
\hline Rarely & $25(0-91)$ & & $53(0-80)$ & & $17(0-256)$ & & $4(0-6)$ & \\
\hline Quantity & & 0.28 & & 0.66 & & 0.75 & & 0.47 \\
\hline$>2$ spliffs/joints & $16(0-120)$ & & $55(0-80)$ & & $20(0-479)$ & & $3(0-6)$ & \\
\hline$\leq 1$ spliff/joint & $28(0-91)$ & & $50(0-80)$ & & $18(0-256)$ & & $4(0-6)$ & \\
\hline
\end{tabular}

* Risk of exposure to occupational hazards known to be detrimental to sperm

Table 3: Correlations of marijuana use with sperm parameters

\begin{tabular}{lccccccc}
\cline { 2 - 7 } & \multicolumn{6}{c}{ Qarijuana use } \\
\cline { 2 - 8 } & \multicolumn{2}{c}{ Quantity } & \multicolumn{2}{c}{ Frequency } & \multicolumn{2}{c}{ Duration } \\
\hline Parameter & $\mathbf{r}_{\mathrm{s}}$ & $\boldsymbol{p}$ & $\mathbf{r}_{\mathrm{s}}$ & $\boldsymbol{p}$ & $\mathbf{r}_{\mathrm{s}}$ & $\boldsymbol{p}$ \\
\hline $\begin{array}{l}\text { Concentration } \\
\left(\mathrm{x} 10^{6} / \mathrm{mL}\right)\end{array}$ & -0.089 & 0.410 & -0.029 & 0.793 & 0.056 & 0.630 \\
$\begin{array}{l}\text { Motility (\%) } \\
\begin{array}{l}\text { Total motile sperm } \\
(\mathrm{x} \mathrm{10})\end{array}\end{array}$ & -0.226 & $0.045^{*}$ & -0.234 & $0.047^{*}$ & -0.141 & 0.201 \\
$\begin{array}{l}\text { Normal } \\
\text { morphology (\%) }\end{array}$ & -0.054 & 0.645 & 0.062 & 0.056 & -0.006 & 0.957 \\
\hline
\end{tabular}

$* p<0.05$

or smoking several times a day demonstrated poorer motility. Duration of use was not found to be deleterious, suggesting that the concentration of $\Delta^{9}-\mathrm{THC}$ at the time of analysis may have a stronger association with suboptimal quality than long-term use. These results mirror findings that exogenous in vitro incubation with $\Delta^{9}$-THC negatively impacts progressive motility in a dose-dependent manner (16). Importantly, we support findings that motility is one of the most predictive factors of achieving a clinical pregnancy (24).

Though quantifying the use of marijuana showed deleterious effects of marijuana use on sperm motility, the precise mechanism of the effects of $\Delta^{9}$-THC on sperm quality remains unclear. Previous studies have reported that high-level sperm DNA fragmentation was detrimental to fertilization and pregnancy rates $(25,26)$. In ongoing investigations, we aim to determine specifically how the habitual use of marijuana affects sperm
DNA integrity. Such testing will allow us to expand on the conventional semen analysis that may show normal parameters in the presence of high levels of DNA fragmentation (25).

The literature on male fertility is consistent in reporting that sperm parameters decrease with age (18). Hence, the finding that younger men in our sample were equally likely to have poor sperm motility as older men was surprising. The difference in reports of marijuana consumption between younger and older men in our sample was not statistically significant and therefore does not explain this finding. However, Pacey et al looked at lifestyle practices and found poorer sperm morphology among younger men which suggested that greater marijuana consumption may be a contributing factor (27). More detailed and objective assessment of marijuana use such as measuring $\Delta^{9}$-THC concentration at the time of analysis is necessary. The results highlight the importance of conducting comprehensive studies of fertility influences that include lifestyle practices.

Most international guidelines for infertility investigations suggest starting with less invasive treatments (especially in cases of unexplained infertility), such as ovulation induction or intrauterine insemination, before attempting the more invasive procedures such as IVF (28). The finding that recreational use of marijuana can have a negative association on motility underscores the clinical relevance of screening for marijuana use to help guide treatment decisions.

Moreover, these findings have implications for counselling men with subfertility concerns on their use 
of marijuana as a recreational drug. Similar to studies that have identified that many women with suboptimal fertility practise a lifestyle that contraindicates their chance of pregnancy (29), these results indicate the need for psycho-education and supportive counselling targeting subfertile men. Further, as data suggest that approximately $10 \%$ of chronic users will transition to dependence (30), counselling the subfertile male population could include informing them of the psychosocial factors that drive and maintain the habit such as certain emotive triggers, time of day for use and concurrent use of other recreational substances.

Some possible limitations of our study design warrant mention. Firstly, these findings are not generalizable to the general male population as the study was cross-sectional and conducted with only male partners of infertile couples. Self-reporting of medical conditions must also be taken into account as underlying anatomical abnormalities may have gone undetected. Although marijuana is commonly used recreationally in Jamaica, it is an illegal substance, and some participants may have hesitated in reporting accurate usage. Due to our small sample size, other recreational substance use (cigarettes and alcohol) was not separated for statistical analysis; however, synergic or additive effects must be considered. In addition, a larger sample size stratified for marijuana use and a longitudinal methodology will allow us to analyse sperm parameters of current users. Nonetheless, even though larger samples are needed to confirm associations, we were able to identify significant findings with our sample.

\section{CONCLUSION}

To our knowledge, this is the first study to quantify reported marijuana use in men undergoing infertility investigations. We found that the quantity and frequency of smoking marijuana had more of an association with sperm quality than the duration for which marijuana was smoked. Highlighted by this study was the need to investigate more sensitive assays than the conventional semen analysis, such as measuring DNA fragmentation and $\Delta^{9}$-THC concentration in semen samples at the time of collection. Additionally, exploring social and environmental characteristics associated with marijuana use (such as quality/potency of the herb, lifestyle and cultural practices) will strengthen future studies and help to understand better the impact of marijuana use on reproductive potential. With the recent interest in the medicinal benefits of marijuana and possibly subsequent increased use, this research is likely to be of international importance to assisted conception.

\section{ACKNOWLEDGEMENTS}

This study was supported by a grant from the New Initiative Grant, Office of the Principal, UWI, Mona, Jamaica. The authors would like to thank the team at The Hugh Wynter Fertility Management Unit, UWI, Mona, Jamaica, in particular, embryologist Mrs Denise Keene. We would also like to thank Ms Shari Brown and Ms Nadia Parkins for their help with recruitment, consenting, data collection and semen analyses.

\section{REFERENCES}

1. Vine MF. Smoking and male reproduction: a review. Int J Androl 1996; 19: $323-37$.

2. Klonoff-Cohen H. Female and male lifestyle habits and IVF: what is known and unknown. Hum Reprod Update 2005; 11: 179-203.

3. Practice Committee of the American Society for Reproductive Medicine. Diagnostic evaluation of the infertile male: a committee opinion. Fertil Steril 2015; 103: e18-25.

4. Vellani E, Colasante A, Mamazza L, Minasi MG, Greco E, Bevilacqua A. Association of state and trait anxiety to semen quality of in vitro fertilization patients: a controlled study. Fertil Steril 2013; 99: 1565-72.

5. Sadeu JC, Hughes CL, Agarwal S, Foster WG. Alcohol, drugs, caffeine, tobacco, and environmental contaminant exposure: reproductive health consequences and clinical implications. Crit Rev Toxicol 2010; 40: 633-52.

6. Trummer H, Habermann H, Haas J, Pummer K. The impact of cigarette smoking on human semen parameters and hormones. Hum Reprod 2002; 17: 1554-9.

7. Practice Committee of the American Society for Reproductive Medicine. Smoking and infertility: a committee opinion. Fertil Steril 2012; 98: 1400-6.

8. Muthusami KR, Chinnaswamy P. Effect of chronic alcoholism on male fertility hormones and semen quality. Fertil Steril 2005; 84: 919-24.

9. Alvarez S. Do some addictions interfere with fertility? Fertil Steril 2015; 103: $22-6$.

10. Weller R, Halikas J. Marijuana use and sexual behavior. Journal of Sex Research 1984; 20: 186-93.

11. Phillips KT, Phillips MM, Lalonde TL, Tormohlen KN. Marijuana use, craving, and academic motivation and performance among college students: an in-the-moment study. Addict Behav 2015; 47: 42-7.

12. Wilks R, Younger N, Tulloch-Reid M, McFarlane S, Francis D. Jamaica health and lifestyle survey 2007-8, technical report. Available from: http:// www.paho.org/hq/index.php?option $=$ com_docman\&task $=$ doc_view\&g $\mathrm{id}=18305 \&$ Itemid=270\&lang=en.

13. Lewis SEM, Rapino C, Di Tommaso M, Pucci M, Battista N, Paro R et al. Differences in the endocannabinoid system of sperm from fertile and infertile men. PLOS One 2012; 7: 1-8.

14. Morgan DJ, Muller CH, Murataeva NA, Davis BJ, Mackie K. Delta9Tetrahydrocannabinol (Delta9-THC) attenuates mouse sperm motility and male fecundity. Br J Pharmacol 2012; 165: 2575-83.

15. Ricci G, Cacciola G, Altucci L, Meccariello R, Pierantoni R, Fasano S et al. Endocannabinoid control of sperm motility: the role of epididymus. Gen Comp Endocrinol 2007; 153: 320-2.

16. Whan LB, West MC, McClure N, Lewis S. Effects of delta-9-tetrahydrocannabinol, the primary psychoactive cannabinoid in marijuana, on human sperm function in vitro. Fertil Steril 2006; 85: 653-60.

17. Lewis SE, Maccarrone M. Endocannabinoids, sperm biology and human fertility. Pharmacol Res 2009; 60: 126-31. 
18. Eskenazi B, Wyrobek AJ, Sloter E, Kidd SA, Moore L, Young S et al. The association of age and semen quality in healthy men. Hum Reprod 2003; 18: 447-54.

19. The Ministry of Justice, Government of Jamaica. The Dangerous Drugs (Amendment) Act 2015. Available from: http://www.japarliament.gov. jm/attachments/339_The\%20Dangerous\%20Drug\%20bill\%202015. pdf.

20. Gui H, Tong Q, Qu W, Mao CM, Dai SM. The endocannabinoid system and its therapeutic implications in rheumatoid arthritis. Int Immunopharmacol 2015; 26: 86-91.

21. Younglai EV, Holloway AC, Foster WG. Environmental and occupational factors affecting fertility and IVF success. Hum Reprod Update 2005; 11: 43-57.

22. World Health Organization. Laboratory manual for the examination of human semen and sperm-cervical mucus interaction. $4^{\text {th }}$ ed. Cambridge: Cambridge University Press; 1999.

23. Kruger TF, Ackerman SB, Simmons KF, Swanson RJ, Brugo SS, Acosta AA. A quick, reliable staining technique for human sperm morphology. Arch Androl 1987; 18: 275-7.

24. Hamilton JA, Cissen M, Brandes M, Smeenk JM, de Bruin JP, Kremer JA et al. Total motile sperm count: a better indicator for the severity of male factor infertility than the WHO sperm classification system. Hum Reprod 2015; 30: 1110-21.
25. Zhao J, Zhang Q, Wang Y, Li Y. Whether sperm deoxyribonucleic acid fragmentation has an effect on pregnancy and miscarriage after in vitro fertilization/intracytoplasmic sperm injection: a systematic review and meta-analysis. Fertil Steril 2014; 102: 998-1005.

26. Practice Committee of American Society for Reproductive Medicine. The clinical utility of sperm DNA integrity testing. Fertil Steril 2008; 90 (5 Suppl): S178-80.

27. Pacey AA, Povey AC, Clyma JA, McNamee R, Moore HD, Baillie H et al. Modifiable and non-modifiable risk factors for poor sperm morphology. Hum Reprod 2014; 29: 1629-36.

28. van den Boogaard NM, Bensdorp AJ, Oude Rengerink K, Barnhart K, Bhattacharya S, Custers IM et al. Prognostic profiles and the effectiveness of assisted conception: secondary analyses of individual patient data. Hum Reprod Update 2014; 20: 141-51.

29. Domar A, Conboy L, Denardo-Roney J, Rooney K. Lifestyle behaviors in women undergoing in vitro fertilization: a prospective study. Fertil Steril 2012; 97: 697-701.

30. Florez-Salamanca L, Secades-Villa R, Hasin DS, Cottler L, Wang S, Grant BF et al. Probability and predictors of transition from abuse to dependence on alcohol, cannabis, and cocaine: results from the National Epidemologic Survey on alcohol and related conditions. Am J Drug Alcohol Abuse 2013; 39: 168-79. 